STUDIA EDUKACYJNE NR 30/2014

VĚRA KOSÍKOVÁ

Pedagogic Faculty

ZČú in Pilsen

\title{
COMMUNICATION STYLES IN TEACHING AND THEIR PSYCHO-DIDACTIC ASPECTS
}

\begin{abstract}
Kosíková Věra, Communication Styles in Teaching and their Psycho-Didactic Aspects [Style komunikacyjne $\mathrm{w}$ nauczaniu i ich psychodydaktyczne aspekty]. Studia Edukacyjne nr 30, 2014, Poznań 2014, pp. 321-329. Adam Mickiewicz University Press. ISBN 978-83-232-2756-4. ISSN 12336688

This contribution, using a research approach, focuses on communication styles in teaching and their psycho-didactic aspects. It analyzes the communication styles from a humanist, non-directive approach perspective, based on empathy and mutual respect. A non-directive communication style encourages the student to become a co-creator of the teaching process, it nurtures his or her curiosity, creativity, his or her own experience and the autonomy in the learning process.
\end{abstract}

Key words: communication styles, psycho-didactic, humanist, non-directive approach to communication, the student as a co-creator of the teaching process, student autonomy

\section{Introduction into the problem}

The research ${ }^{1}$, which focuses on communication styles in teaching, was carried out in 2012-2013 as a part of the "Communication Styles in Teaching and their Psycho-Didactic Aspects" project, at the Pedagogic Faculty of the University of West Bohemia in Plzen.

The research contributed to a deeper understanding of problems of learning processes of students and of teaching strategies of teachers. It fo-

${ }^{1}$ Including preliminary research, see: V. Kosikova, V. Holeček, J. Krotký, Projekt Způsoby komunikace ve výuce a jejich psychodidaktické aspekty a jeho dílči výsledky zaměřené na spolupráci studentů technické výchovy a psychologie, [in:] Interdisciplinární vztahy mezi technickými, humanitními a společenskými vědami, Praha 2013, p. 1-11. 
cused on communication styles in teaching, analyzed non-directive communication, which views the student as a partner and co-creator of the teaching process.

The theoretical foundation of the non-directive approach is the humanist psychology of C. Rogers (1997), which encourages the student's autonomy and his or her co-responsibility for the teaching effectiveness. Similarly, the personalistic approach, as emphasized by Helus ${ }^{2}$ works with the assumption that the student is a co-creator of the teaching process. Harbo ${ }^{3}$ speaks about the humanization of education in connection with the characteristics of forthcoming teaching goals, which are based on effective communication in pedagogic situations, on cooperation and student-teacher interaction.

A precondition for the mentioned foundations for effective communication is such an approach of the teacher to the student, which furthers the student's potential, his or her autonomy, which connects to the student's experience and perceives communication as a reciprocal dialogue between teacher and student. These requirements are met by non-directive communication, which is based on a partner-level approach that supports the student's autonomy and his or her participation in effective teaching. Based on this assumption, research goals were formulated, which were further processed into research questions.

\section{Goals of the research survey}

The goal of the empiric survey was to find such a communication style, which would best suit the student's learning processes as well as the teaching methods of the teacher. Based on the results of preliminary research, where communication styles were described with regards to non-directive communication, it was tested, whether a non-directive communication style supports the autonomy of the student and his or her participation in effective teaching, whether it thus meets the requirements for effective communication.

3 basic research questions were formulated in the research:

1. To which extent is communication being applied that is based on empathy, mutual regard, tolerance and respect?

2 Z. Helus, Uplatňováni personalizačního zřetele v pojetí výuky, [in:] Psychologie ve vzdělávání učitelů a v jejich profesní činnosti, Plzeň 2009, p. 6-15.

${ }^{3}$ T. Harbo, Humanizace vzdělání a současné teorie kutikula, Pedagogika, 1991, 40, 3, p. 247256.

${ }_{4}^{4}$ V. Kosikova, V. Holeček, J. Krotký, Projekt Způsoby komunikace, p. 1-11. 
2. To which extent is communication being applied that supports the student's personal experience and autonomy in the learning process?

3. To which extent is communication being applied that supports curiosity, creativity and the cooperation of students?

\section{Methods, research sample}

The carried out quantitative-qualitative research draws from content analysis of video recordings of classes. The footage was analyzed using the "Humanist Upbringing Observation System"5, which was modified for the needs of the research (individual observed signs of non-directive communication were verified and described as part of the preliminary research ${ }^{6}$ ).

The modified observation protocol contains 3 basic characteristics of non-directive communication: communication based on empathy, mutual regard, tolerance and respect, communication supporting curiosity, creativity and cooperation of students, communication supporting the student's personal experience and autonomy in the learning process.

As stated above, video footage was used in the research. There were 40 video recordings of classes, 10 teachers of secondary schools from the Plzen District, which means that for each teacher video recordings of 4 classes were available. The teachers taught humanities as well as science.

The goal of the content analysis of the video recordings was to determine whether the monitored phenomena were present in abundance or not at all, under which conditions, whether assessment as well is carried out in line with non-directive communication.

The basic method of this research, as stated above, was observation a combination of quantitative data (in terms of count) and qualitative analysis of the data acquired was used. The fundamental moment, as emphasized by proponents of qualitative research, e.g. Hendl7, is the analysis of the data acquired. To what extent should it be interpreted, analyzed, augmented by subjective positions? The goal should be to present an accurate report, with a minimum of interpretation, to provide an accurate description. This description is founded in accurate and word-for-word recordings of the classes observed.

5 Authors: D. Jelinkova, P. Gavora, in: P. Gavora, Úvod do pedagogického výzkumu, 2. Vydání, Paido 2010, p. 261.

${ }^{6}$ V. Kosikova, V. Holeček, J. Krotký, Projekt Způsoby komunikace.

7 J. Hendl, Kvalitationí výzkum, Praha 2008. 
The evaluation also made it possible to observe whether there are any significant differences between individual teachers. Each observation protocol contains an accurate log of the lesson and a comprehensive evaluation. Each recording protocol contains a record of the count of the monitored phenomena, if they were observed, further, there is a detailed log of the lesson, showing in what context the monitored phenomena occurred.

\section{Results of the empiric survey}

The observed phenomena were described and analyzed in detail, within the context in which the given phenomena occurred (the observation protocols contain detailed lesson logs, including word-for-word records of teachers' utterances - see examples, see appendix).

The results are presented according to the count of occurrences, according to how often and in what context they were present in the classes.

Communication Based on Empathy, Mutual Regard, Tolerance and Respect. When we speak about non-directive communication, we see it in connection with empathy, mutual regard, tolerance and respect. The given characteristic was represented in almost all classes, by all teachers, regardless of their specialization (individual characteristics are supported by wordfor-word quotations by evaluators - master degree students of teaching)

1. the teacher was polite towards the student - "the teacher demonstrated that he is listening, when the student spoke";

2. the teacher encouraged the student - "he praisingly repeated the response of the student";

3. the teacher positively appraised the student (he appraised the student's effort even though the student's answer was incorrect) - "Do not look for a right or wrong answer in this, let us go it over together;

4. the teacher expressed fondness of all students - "the teacher did not show his antipathy towards some of the students";

5. the teacher allowed the students to initiate their own views, problems, suggestions... - "who has a different opinion?"; "who would like to add, append something to this topic...?";

6. the teacher tolerated a difference in opinion - "Okay, you believe that there will be no more newspapers, does share his opinion? And can he or she justify it?";

7. the teacher admitted having made an error. 
Example - the biology teacher encourages students to assess the performance of their fellow student, where after he admits his own mistake:

Teacher: "I will now let you say, whether there was something you didn't like, or something you did like, or is there something specific you would like to commend?"

"Okay, Mathew." student: "I liked it, it was nice, nicely prepared, but I thought that she spoke a little too fast and unintelligibly". Teacher: "What would you emphasize, what did you like?" students: "The pictures."

Teacher: "Do you know, what these cotyledons are?" students: --- The students are silent, the teacher explains and continues: "Take out the cotyledons you were supposed to bring with you".

Student: "Mister teacher, you haven't told us to bring any such leaves." teacher: "Right, yes, I did not think of that. I am sorry."

Communication Supporting the Student's Personal Experience and Autonomy in the Learning Process. The teachers often inquired about the experience students had with a given topic, often asking open questions; autonomous student assessment based on a complex analysis of their performance and the development of an individual working approach was less often to be seen.

1. the teacher gives the student an opportunity to present his or her own experience, view "the teacher often asks, who has personal experience with the topic at hand, what the students would like to add, based on their own experience";

2. the teacher built on the student's experience;

3. the teacher was checking whether the students have understood someone else's opinion - "who will comment on what your mate just said?";

4. the teacher asks open, productive questions, like: "what are the features of the visual type? Paul, how did you recognize that this is a visual type?";

5. the teacher purposefully encouraged the autonomous assessment of students - "usually during presentations, when teachers frequently asked the students how they would judge the performance of their classmates";

6. the teacher made use of self-assessment by students - "how do you see it, how well did you do?";

7. the teacher gave the student room to use his own working approach.

Example - personal working approaches were to be observed during the preparation and realization of presentations:

Teacher: "Last time I told you, how you can prepare a presentation. It is up to you, how detailed your work will be, how many pictures you use and how you will comment on them." 
Teacher: "What did you write about home processing of crops? How, for example, do you process them at home?" student 1: "We make marmalade." student 2: "Strawberry cocktail." student 3: "Baked tea." student 4: "Juice." Teacher: "See, I told you, you can approach this in whatever way suits you best. Join up in groups and try to find what other uses there are..."

Communication Supporting Curiosity, Creativity and Student Cooperation. Communication leading to development of curiosity and creativity of students was less represented than the above types, nevertheless, many examples of developing curiosity and creativity were described (independently of the subject). In almost all cases, the observation protocols speak of a friendly atmosphere, also in connection with positive assessment:

1. the teacher's assessment is carried out in a friendly atmosphere - in nearly all instances, as stated by the evaluators;

2. assessment was of a high motivational value for the students - "the assessment derived from the principle of positive assessment, students were praised, students were often encouraged...";

3. the teacher gives the students the opportunity to ask questions - "the teachers often prompted the students to ask questions";

4. students worked in pairs or in groups - "group work was often used during oral testing, but also in problem solving";

5. the teacher asks the students for propositions, solutions, opinions, which do not have to be unanimous - "do all agree, does anyone have a different opinion?";

6. the teacher asks divergent questions - "questions to be answered by the students in varying ways were almost non-existent";

7. the teacher allows solutions to be worked out intuitively (rather than systematically, using logic).

An example of intuition used by students in a psychology class:

Teacher: "So I ask you again, how would you understand this?" (this was about difficult life situations, author rmk) Student: "I made up a story" Teacher: "Great, how about the others?" Students: "we figured it out, too, someone has even a situation described, from our own class, how they would react in different situations..."

An example of a positive assessment by a teacher:

Teacher: "Here, you completed all the tasks I asked of you, the girls consulted ahead of time, they showed me the consultations, when we agreed on something, then they delivered it, the only reservation I have, is about the presentation, Suzy will try to count, so she speaks a little slower and Hannah, she could not decipher 
some of the words, but let's say this was only because you were stressed. As for the content, everything was fine."

Teacher: "So, how do we assess this, what do you propose, Mathew?" student: "I liked it, I understood it, too."

Teacher: "So, for $75 \%$ the grade is One, aside from minor deficiencies it was comprehensible."

"So they get a One for 75\%?" student: "Agreed, thank you."

\section{Conclusion}

The empiric survey focused on these research questions:

1. To which extent is communication being applied that is based on empathy, mutual regard, tolerance and respect?

2. To which extent is communication being applied that supports the student's personal experience and autonomy in the learning process?

3. To which extent is communication being applied that supports curiosity, creativity and the cooperation of students?

As was described, the content analysis of the video recordings was based on the count of the monitored phenomena, these phenomena were, at the same time, written down authentically, in the context in which they occurred. The first research question, namely to what extent communication based on empathy and regard for the student was utilized, can be answered by stating that in nearly all the classes a positive atmosphere was prevailing, there was communication between the teachers and students based on mutual regard, tolerance and respect. Teachers supported the students, they were interested in their opinions, they encouraged the students not to be afraid to ask and also to answer the teachers' questions. Humor was often present in the classes, what was highly valued by the students, as well as was the forthcoming and helpfulness of the teachers.

The second research question, determining the extent of utilization of communication supporting the experience of students and their autonomy, can be answered by stating that the students' experience was fostered by the majority of the teachers, regardless of their specialization. The teachers asked questions relating to the current experience of the students, they connected to their experience and used it to convey new subject matter. The second part of the question, the one focusing on developing student autonomy, wasn't as much represented. The autonomy of students was made use of during independent work, when developing a personal working approach (when preparing presentations and homework), but autonomous 
assessment, for example, was not to be seen all that often, and if it was, then it was lacking a deeper analysis of the performance - be it of the student him/herself, or a classmate.

Least represented was the third area of communication, formulated by the research question, namely to what extent was communication applied supporting curiosity, creativity and cooperation of the students. The cooperation of the students, as was stated, was present in over a half of cases, creative tasks, however, were less common. It was revealed that the weakest link in the classes was the development of intuitive and divergent thinking. Questions as well as tasks set by the teachers were rather directed at testing of acquired knowledge or skills of the students, there was no room for systematical development of meta-cognition and creativity.

The results, though deriving from a small sample, still hint at a tendency of teachers to draw students into the teaching process, to develop dialogue and to connect with their experience.

In conclusion it can be stated that non-directive communication breaks down the students' possible worries about failure, whereby it allows the students to be active, not to fear in engaging themselves in the lessons, to ask questions, to argue, to express their opinions etc. Non-directive communication supports the student in his or her learning process also as a co-creator of the teaching process, it develops his or her curiosity, creativity and autonomy, although not to an extent (according to gathered data) that effective teaching should deserve.

The results only apply to a limited sample of the survey carried out.

\section{BIBLIOGRAPHY}

Harbo T., Humanizace vzdělání a současné teorie kutikula, Pedagogika, 1991, 40, 3.

Helus Z., Uplatňování personalizačního zřetele v pojetí výuky, [in:] Psychologie ve vzdělávání učitelů a v jejich profesní činnosti, Západočeská univerzita, Plzeň 2009.

Hendl J., Kvalitationí výzkum, Portál, Praha 2008.

Gavora P., Úvod do pedagogického výzkumu, 2. Vydání, Paido 2010.

Kosíková V., Holeček V., Krotký J., Projekt Způsoby komunikace ve výuce a jejich psychodidaktické aspekty a jeho dílčí výsledky zaměřené na spolupráci studentù technické výchovy a psychologie, [in:] Interdisciplinární vztahy mezi technickými, humanitními a společenskými vědami, České vysoké učení technické, Praha 2013.

Rogers C.R., Zpưsob bytí, 1. Vydání, Portál, Praha 1998. 


\begin{abstract}
APPENDIX
The appendix contains samples of authentic lesson logs, which clearly illustrate under which circumstances communication was taking place in the classroom.

"The pedagogue was speaking in a calm but strong tone, in standard language, choosing a way of delivering information adequate to the age of the group. The communication with the class was outstanding, she made an effort to engage all students (even those who did not hold up their hands). She only seemed "reserved" (almost no smiles) at the start of the lesson. Overall, though, she was praising the class and individual students, always after correctly answering a question."

"When the teacher made an error (a single time in five lessons), he praised the students for noticing it. It was noticeable that the students were not afraid to alert the teacher about his error - even though the error was inadvertent and it seemed that the students perceived it that way."

"... after the end of repeating followed the testing. The tested student seemed surprised and he went to the blackboard uttering minor remarks. The testing went down as follows: the pedagogue is sitting at her desk and the tested student sat down at the front row desk opposite. The other students in the class have been assigned independent work, which the teacher explained beforehand. They work independently. The pedagogue asked the tested student two questions, handing him a piece of paper with the same questions. Thus the student was given enough time to prepare, of what, however he did not make use. The testing was conducted in a calm atmosphere and the final grade was explained. First, however, the teacher asked the tested student how he thought his performance was. The student was not able to express himself, explanation followed, about where he did well and where he did not."

"When checking the independent work, the students found an error (apparently already made in the previous lesson) and alerted the teacher to it. The pedagogue apologized and went on: "Check the next task, to see whether I haven't made an error there, too". She praised the class for their activity in the lesson and then started to explain new material, what was complemented by a discussion. In the process of this, she asked open questions, the students expressed their opinions, the teacher, using further follow-up questions, was making sure the students are keeping up with the pace, that they understand. Whatever uncertainties there were, she addressed them readily, providing various examples. For the end of the lesson she had prepared illustrative examples, which clarified all remaining questions. The lesson was conducted in a friendly atmosphere, the students freely asked questions when they needed something explained, the pedagogue encouraged their curiosity. She used very nice explanations for the new material, she connected it to previous lessons. The students had no trouble engaging in the lesson."
\end{abstract}


